\title{
Insurance as a Factor for the Development of the Agricultural Sector in the Republic of Serbia
}

\author{
PILJAN Ivan ${ }^{21}$, COGOLJEVIĆ Dušan ${ }^{22}$, PILJAN Tatjana ${ }^{23}$
}

\begin{abstract}
Insurance in the agricultural sector is a special sort of property insurance applied to agricultural manufacturers in the aim of preventing the loss of profit made in agricultural activities. It is not limited to crops and fruitage, rather it refers to livestock, domestic and wild animals, and it can also be applied to greenhouses, in forestry and aquaculture.

This paper points out to characteristics of crop and fruitage insurance as an instrument for risk management applied in Europe and Serbia. Different insurance systems are analyzed here with an emphasis on the insurance of one type of risk, combined insurance and crop insurance.

Different forms of crop and fruitage insurance are given here, with a special emphasis on the share of insured areas, share of insurance premiums in the insured sum, realized technical result expressed through a ratio of paid claims and paid insurance premiums by the insurer, as well as the number of subsidies which the state is using to partially compensate farmers for the costs of insurance premiums. Has a special social and ecological significance, wherein it is the driver of rural development at the same time.
\end{abstract}

Keywords: insurance in agricultural sector, paid claims, subsidies, crop and fruitage insurance, risk management

JEL: G21, G2, G23

UDC: $631: 368(497.11)$

COBISS.SR-ID 265412364

\section{Introduction}

In the Republic of Serbia, a significant portion of the work force, that is around 600,000 people older than 15 , are relating their existence to the agricultural sector.

In mid-May, 2014 the Republic of Serbia was faced with catastrophic floods due to extreme and for decades not seen precipitation. Based on the report on the estimation of occurred damages total effects were somewhat around EUR 1.7 billion, i.e. resulting direct damage was $2.7 \%$ of the GDP. It was also estimated that in the entire territory hit by floods there were 32,500 farmers found in critical situation, most of whom (around 26,300) were small farmers

21 Faculty of Business Economics and Entrepreneurship, Belgrade, Serbia, email: ivan.piljan@vspep.edu.rs

22 Faculty of Business Economics and Entrepreneurship, Belgrade, Serbia, email: dusan.cogoljevic@vspep.edu.rs

23 Faculty of Business Economics and Entrepreneurship, Belgrade, Serbia, email: tanja.piljan@vspep.edu.rs 
cultivating land up to 2 acres. Around 80,000 acres of arable land was flooded, whereas a significant portion of agricultural land (around 11,500 acres) was affected by a large quantity of sludge and other waste material, due to which that part of the land became unusable for a certain period of time. Planted crops and many agricultural facilities, as well as agricultural mechanization, were destroyed during the crisis (Đordević, Stanković, 2015). In 2017, drought has affected the entire territory of the Republic of Serbia and has caused massive damage in the agricultural sector and its consequences are still being summed up. If we add to this the possibility of a potential epidemic of diseases that hit animals, fish, agricultural, fruit and other crops, then we can completely understand why the theme of this paper is so topical.

Sustainable development concept requires, with respect to the principles of market economy, the need to manage risks, especially in sectors often susceptible to unpredictable situations on which there can be no greater influence. Risk reduction in the agricultural sector via adequate management is today an unavoidable need which is there to compensate for the possible consequences due to natural weather disasters to a greater extent. Experiences of developed countries have shown that the best protection in such situations has been accomplished by applying the institute of the appropriate insurance.

Insurance is a form of risk management which is used to restrain potential losses. One of the conventional definitions says that insurance transfers the risk of losses from one entity to another in exchange for a premium or a guaranteed, measurable loss which is used to prevent greater or possible irrecoverable loss (Cogoljević et al., 2017).

Insurance in the agricultural sector is technically a very complex activity and implies that we understand complex biological processes and cause-and-effect relations in agriculture (which are not always easily noticed) by the insurer, with the necessity of establishing the relation between the loss being insured and the cause of that loss.

\section{Agricultural insurance in Serbia}

Agriculture as a sector of economy is of vital importance for the Republic of Serbia and its overall social and economic development. Status of agricultural sector is specific because in addition to its economic significance, it also has a special social and ecological importance, whereas it is also a driver of rural development. Agriculture contributes to national wealth with a significant share in the making of GDP (according to data 7.7\% for the year 2016) and in the overall employment of the population (around 20\%). For several decades, agricultural sector has been one of the leading Serbian exporters with hundreds of millions of euros per year. At the same time, we've witnessed numerous natural disasters and epidemics of contagious diseases that have made great damages to agricultural households and livestock fund in the previous period.

Unfortunately, due to global warming, climate conditions have changed significantly, hence we can expect more unpredictable disasters in the future on which people can almost never influence. People can neither stop epidemics of lethal diseases hitting domestic animals, whose carriers of infection are multiplying on a daily basis. Therefore, what every farmer can and should do to protect their crops and animals is to insure them.

Two basic types of insurance in agriculture currently present on the insurance market in Serbia are:

1. Crops and fruitage insurance cover the loss of yield as a consequence of damaged (destroyed) agricultural crops from the insured risk. Most common coverages in Serbia are coverages from predominating risks: hailstone, fire and thunder strike, whereas the most common is hailstone. We can also add risks from a storm, flood, frost as well as insurance from the loss of seed quality, loss of quantity and quality of fruit and table grapes and such. 
2. Livestock fund insurance most often covers the risk from an unfortunate event and disease on a single or flotation basis. For this type of insurance in agriculture, the risks of death or forced slaughter in predefined cases can be additionally covered, as well as the risks of illness caused by improper diet, swallowing of foreign bodies, loss of calves during delivery or loss of breeding ability of livestock.

In addition to the aforementioned, it's been brought to our attention that there have been a number of insurances concerning the risk of drought for certain crop cultures, as well as insurance of crops against excessive precipitation. Even though these types of insurances in agriculture are still in their beginning, we can say that the offer of insurance companies in the agricultural insurance on our market is constantly increasing and that this type of insurance is gaining more and more attention.

\section{Subsidies}

Insurance premium subsidies are, globally speaking, the most common model for encouraging the development of agricultural insurance which the states are using to stimulate insurance policies covering the risk of losing profit in agriculture. This year, the Republic of Serbia has approved insurance premium subsidies by making the Decree on the regression of insurance of animals, crops, fruits, nurseries and young perennials, which is an important incentive, especially in the conditions of large budgetary limitations. According to this Decree, registered farmers have the right to regress their insurance in the amount of $40 \%$ of the insurance premium without taxes on non-life insurance premiums if they insured animals, crops, young perennials, nurseries and fruitage (Službeni glasnik RS, 61/2017). Despite these incentives, market penetration in Serbia is still on a significantly low level, almost negligible, which points out that the insurance premium subsidies are not enough for a greater expansion of agricultural insurance on our market.

According to the data gathered from the Association of Serbian Insurers, the state is subsidizing $40 \%$ of the costs of insurance for farmers when buying their policies. Precondition is that households are registered, and land not bigger than 20 acres.

Republic of Serbia is one of few countries that, in addition to having subsidies for insurance policies, makes up for damages which are the consequence of natural disasters. Everywhere in the world, legal obligation of farmers is to insure their own crops. Good example is Romania in which farmers lose their right to subsidies unless they are insured. They think we should follow in their footsteps.

In that case, out of our 3,700,000 acres of currently processed crops more acres would be insured than the current 250,000 to 300,000 . Insurance premiums in our country account for only 2 billion dinars. In this way, they participate with only $3 \%$ in the field of non-life insurance.

Reasons for such a situation are low standard of living, farmers' lack of information on the advantages of insurance, hence a common opinion that the state should make up for the damages caused by natural disasters. Damages should be made up for by the insurance companies and the state is there to give a helping hand.

For the development of agricultural insurance in the Republic of Serbia, it is necessary for farmers to more adequately stimulate the insurance of their own production. It is necessary to create long-term solutions that would include: stable portfolio (with risk diversification), adequate system of subsidies (at an acceptable level for all parties), development of preventive funds (as risk mitigation measures), products tailored to the needs of the insured (with the necessary levels of coverage) and programs that will increase awareness of the risks in agriculture and improve the availability of this type of insurance. One of the possible solutions that could accelerate the market is a model in which, as a condition for obtaining subsidies in agriculture by the state, the obligation to pre-contract appropriate insurance coverage would 
be introduced. This would result in a multiple effect, on the one hand, they would have predictable revenues of agricultural producers, and on the other hand, the state would protect investments in the form of subsidies in agriculture and, in addition, protect the state budget from further unplanned expenditures. It should not neglect the positive effect on the insurance industry in general, but also return effects in terms of development of preventive measures and education about existing risks in agricultural production and measures to overcome them.

Only by mutual engagement and synchronized operation of the public sector and the insurance industry visible and positive developments in this area can be achieved: insurers in their domain should offer the market an adequate product, in terms of comprehensiveness (covering more risks), clear and as simple as possible defining the terms of insurance and tariffs and easier accessibility to insureds which will be of unambiguous benefit for everyone, including agricultural manufacturers, public sector and insurance industry. By model of developed world markets the other part of the job must be taken over by the state through adequate subsidy systems, models of public-private partnership and the adoption of appropriate legal and secondary legislations in this field. By common engagement, it is necessary to work on the development of consciousness through intensive education of potential insureds about the existence of risk in agriculture, as well as the importance of insurance in terms of protection and improvement of agricultural production. In time to come, establishing good collaboration between the insurance industry and the public sector, on improving the situation in the Republic of Serbia, will be crucial for exploiting developmental opportunities, which certainly exist in this extremely important field.

\section{Insurance of crops and fruits}

Except from hail, fire and lightning strike, crops and fruits can be insured from the storm, autumn and spring frost, floods, as well as loss of quantity and quality. (Generali insurance, 2017).

The height of insurance premium depends on several factors, and some of them are: plant species, location where the crops and fruits are located, selected types of risk for coverage.

The insurance premium is paid on the sum of insurance, which is determined on the basis of expected yield per hectare and one kilogram.

Insurance is probably the best instrument for risk management. It appears as an important factor of stability of each production, including plant production, because it compensates for losses in production and enables its continuing process.

In recent years, there have been more and more thinking about yield insurance of several or all kinds of risks which is present in developed countries, insurance of value of production and income, as well as insurance based on weather indexes, where the primary consideration is the possibility of using time derivatives in agriculture. Very important parameters related to functioning of insurance of crops and fruits are the size of the insured areas, participation of insurance premium in the insured sum, technical result as a ratio of paid claims and collected insurance premiums and the scope of state subsidies for the reimbursement of insurance premiums.

\section{Contracting of crops and fruits insurance}

The insurance of crops and fruits provides the possibility of insuring arable and vegetable crops, fruits, grapes, planting material, trees and fruit seedlings.

Crops and fruits are insured from the hail, fire and lightning strikes, storms, loss of quantity and quality of fruit fruits and table grapes, winter frost, droughts, floods and loss of income (due to natural risks or the risk of price reduction). (Dunav insurance company, 2017).

Desiring to preserve and insure their hard work many manufacturers are deciding to contract crop and fruits insurance. This is definitely a good choice, but as with all other types 
of contracts and in this case, it is necessary to pay attention to contractual stipulations and familiarize with the conditions of insurance of the company with which the insurance is concluded.

It is important to emphasize that it always starts from basic risk insurance, and additional risks are specifically concluded, so after the conclusion of the insurance contract subject of insurance (e.g. wheat) is insured from the hail, fire and lightning strikes, but also from e.g. storm.

In order for the insurer to take on obligations, the insured person is obliged, after signing the insurance policy, to pay the premium, in full or in instalments (as agreed by the parties).

The insurance of crops and fruits contract lasts most often until the end of the vegetation season, but it can also be concluded a multi-year insurance, for which most commercially available discounts are obtained.

The insured, regardless of the concretely high yield, can be secured on a lower yield therefore, the lower premium will be calculated, but accordingly, the sum insured is lower.

This option is left to the selection of the insured.

If it comes to the realization of risk, the insured is obliged to report the damage as soon as possible. Some companies insist on a written application, in some companies insured can report the damage by phone, or orally at the counters of the company where officers further fill out the necessary forms.

The damage assessment can be preceded i.e. pre-assessment and final. In the case when the assessment is preceded i.e. pre-assessment - the final amount of damage is not determined, but only descriptively determines the condition of crops and fruits, nature and degree of damage and other elements, which are of importance for the subsequent final determination of the damage. (Marjanski, 2012)

Pre-assessment is done during vegetation, when the risk occurs (e.g. hail in July on corn or soybean). Then the record is made, photos are taken, the date of the hail should be noted in the record, condition of the crops, breaks, damage of leaves, broom, pods, burliness of hail, density and intensity of falling, duration, etc. It is mandatory to state phenophase in which the crop is located, because the damage varies depending on the development phase of the crop (for example, soya bean will be more regenerated if the hail strikes before the flowering, but if the hail strikes before the pods are formed, the damage is much greater).

Certainly, it is very difficult in agriculture to establish the exact percentage of damage, because each year is different from the previous one and in each individual vegetation there is a completely unique aggregation of weather conditions, agrotechnics, plant compositions, phenophases and other influences.

However, based on empirical results, experiences, agricultural experts can assess very accurately the amount of damage. For example, if it is a matter of estimating damage of the hail on wheat that is before harvest, it is certain that the hail will shake the grain out of its ear and this is direct damage; therefore, the damage is determined by counting the number of grains on several locations on the plot on one square meter and it comes to a damage through a recalculation.

The same goes for soya bean.

After assessing the damage, the insured if it does not agree with the assessment has the right to appeal within 3-8 days (depending on the company), and the insurer is obliged to reevaluate, this time through the commission. If the insured is not satisfied with the assessment, may file an appeal again and then the insurer and the insured are obliged to choose together an agricultural expert from an independent house, who did not participate in the previous procedure for the assessment of damages. (Ostojić, 2007) 
When the damage is determined, the insurer is obliged to compensate the damage, in money, to the insured within 15 days from the liquidation of the damage. (Zakon o osiguranju, SG RS, 129/2014)

Damage estimated at $5 \%$ and less is usually not compensated by all companies (5\% is considered as an integral franchise). Consequently, only the damage of $6 \%$ percent or more are paid. For example, if the damage is estimated at $100 \%$, the insured will be paid $95 \%$ of the insurance sum. This may also depend on the conditions of the insurer, or by the contract itself wherein additional clause can be differently arranged. This is something that should definitely be well informed before signing the insurance contract.

The idea of insurance is not that the damaged individual is enriched (this is often the subject of fraud) but to not lose financially due to "bad luck" during a disaster (fire, hail, flood, etc.). (Piljan et al., 2017)

Insurance in agriculture has great potential for development on the Serbian market, because only nine to ten percent of arable land is now insured. Due to the increasingly frequent weather disasters there is a need for new types of insurance, which is also a new business opportunity for insurance companies. This is confirmed by the recent example when snow in May surprised raspberry producers and destroyed them a good part of the crops, and did not have the necessary insurance that would compensate for the damage.

The state and the insurance companies should work on educating the population about the importance of insurance, both crops and households.

Ignorance about the possibilities of insurance often leads farmers to the wrong path, so they do not know when they have insured crops and when they have insured plant.

\section{Conclusions}

Republic of Serbia is not a welfare state, but a state of "limited" resources.

Quickened economic growth and higher productivity in all sectors, including the agriculture, are a necessary condition for sustainable development. Economic and social consequences of natural disasters are pointing out to the need for changing not only institutional, but also individual behavior in order to more significantly mitigate possible consequences. For as long as nature "serves" us risks, insurance is the necessary instrument in risk management and in the function of appropriate protection of agricultural producers.

There is probably not one agricultural producer that hasn't got the desire to insure themselves from potential risks, i.e. potential consequences of natural disasters. Considering a multi-year unfavourable financial position of the majority of producers, the question is whether they represent a sphere of interest of insurance companies or not, given the fact they base their "calculations" on rules, i.e. "law of large numbers". Solution exists only if the state intervenes in a common interest.

For year, the Republic of Serbia has been subsidizing insurance premiums for agricultural households and in a very large amount and that subsidy is significantly contributing to the growth of insurance in agriculture. The level of coverage is still far from satisfactory. It is important to know beforehand what is insured and from what risks. Insurance users can be satisfied with their insurance, i.e. their expectations can be met only if they are introduced with all the domains and limitation of their insurance coverage before the damage occurs.

Considering the importance of agriculture for the overall economy of the Republic of Serbia, we could also say we are responsible to find the appropriate insurance growth model in this field.

Agricultural insurance should be legally obligatory, primarily for agriculture producers using state subsidies because in that way we could avoid uncertainties like what, how and when to insure. 
Awareness of farmers on the need for insurance in Serbia is still unsatisfactory and the problem is also that farmers don't have enough information on what insurance they need in order to be protected in the best possible way. Even though natural disasters hit Serbian agriculture almost every year, farmers are still "looking at the sky" and hoping that trouble won't find them. Farmers should decide on whether they will insure their crops or not, and insurance companies should adjust their offer to farmers' needs.

Insurance companies are meeting farmers' needs by enabling them to pay the insurance policy after the harvest, i.e. picking.

The biggest problem is when farmers and the state buy and recapitalize the policy and suffer a damage which is not insured. Drought and frost are something climate changes will bring: farmers will most definitely be more interested to fight them with insurance policies.

\section{REFERENCES}

1. Avdalović, V., Petrović, E., (2011). Menadžment rizika i osiguranje, Ekonomski fakultet, Niš, Srbija.

2. Cogoljević, D., Piljan, I., Piljan, T., (2017). Upravljanje rizicima u osiguranju, Visoka škola za poslovnu ekonomiju i preduzetništvo, Beograd, Srbija.

3. Dunav osiguranje, (2017). Opšti uslovi za osiguranje useva i plodova, 2017, Novi Sad, Srbija, (dostupno na: http://www.dunav.com/portfolio/usevi-i-plodovi/)

4. Generali osiguranje, (2017). Opšti uslovi za osiguranje useva i plodova, Beograd, Srbija, (dostupno na: http://www.generali.rs/fizicka_lica/poljoprivreda.964.html)

5. Đordević LJ., Stanković V. (2015). Analiza uticaja šteta od elementarnih nepogoda na rezultate popisa, Republika Srbija - Republički zavod za statistiku, Beograd.

6. Mandić, V. (2012) Osiguranje u poljoprivredi, Makroekonomske analize i trendovi, Ekonomski institut, Beograd, Srbija, vol. 217, str.39 (dostupno na: http://www.ecinst.org.rs/sites/default/files/mat-kratki/gostautormat217.pdf)

7. Marjanski, V. (2012). Ugovor o osiguranju, Pravni fakultet, Novi Sad, Srbija.

8. Ostojić, S. (2007) Osiguranje i upravljane rizicima, Data status, Beograd, Srbija.

9. Piljan, I., Cogoljević, D., Piljan, T. (2017). Osiguranje, Visoka škola za poslovnu ekonomiju i preduzetništvo, Beograd, Srbija.

10. Pravilnik za regresiranje osiguranja u poljoprivrdi, Službeni glasnik Republika Srbija, br. 61/2017.

11. The World Bank, 2009, Reshaping economic geography, Quebecor World, Washington, DC, United States, (dostupno na: https://openknowledge.worldbank.org/discover)

12. Zakon o osiguranju, Službeni glasnik Republika Srbija, br. 139/2014.

\section{Article history:}

Received 7 May 2018

Accepted 17 June 2018 